\title{
Jolanta Chluska
}

Politechnika Częstochowska

e-mail: jchluska@zim.pcz.pl

WYNIK FINANSOWY SZPITALA ASPEKTY INFORMACYJNE I DECYZYJNE

\section{NET PROFIT OF A HOSPITAL - INFORMATION} AND DECISION-MAKING ASPECTS

DOI: $10.15611 /$ pn.2017.471.08

JEL Classification: M40, M41, M42, M49.

Streszczenie: Szpital jako podmiot leczniczy zobowiązany jest do ustalania wyniku finansowego działalności i prezentowania jego wartości w sprawozdaniu finansowym oraz innych sprawozdaniach. Kierownictwo jednostki, a także inni decydenci wykorzystują informacje z systemu rachunkowości jako uzasadnienie przemian i restrukturyzacji. Liczne zmiany systemowe w opiece zdrowotnej wymagają stabilnej podstawy decyzyjnej. Rolę taką może spełniać wynik finansowy. Artykuł prezentuje informacyjne aspekty wyniku finansowego szpitala w procesach decyzyjnych. Celem artykułu jest podkreślenie istotnej roli wyniku finansowego w ocenie dokonań podmiotów leczniczych - szpitali oraz podejmowaniu decyzji zarządczych przez kierownictwo zakładów i otoczenie. Jako narzędzia badawcze wykorzystano analizę literatury przedmiotu, aktów prawnych oraz sprawozdań finansowych szpitali.

Słowa kluczowe: wynik finansowy, zarządzanie szpitalem, rachunkowość.

Summary: Hospital, as a healthcare unit, is required to determine the net profit of own activity and present its value in the financial statements and other reports. The management of healthcare units and other decision-makers use information from the accounting system as a justification for changes and restructuring. Numerous changes in the health care system require a stable basis for decision-making, which may be net profit. The article presents information aspects of the hospital's net profit in the decision-making processes. This article aims to underline the important role of net profit in the assessment of the achievements of medical entities - hospitals - and in decision-making by management of hospitals and other stakeholders. The analysis of literature, legal acts and hospitals' financial statements were used as research tools.

Keywords: net profit, management of a hospital, accounting. 


\section{Wstęp}

Szpital jako podmiot leczniczy, ale także jako podmiot gospodarczy zobowiązany jest do ustalania wyniku finansowego działalności oraz prezentowania jego wartości w sprawozdaniu finansowym i innych sprawozdaniach, w tym sprawozdaniach o charakterze wewnętrznym przeznaczonych dla kierownictwa zakładu oraz innych interesariuszy. Szpitale jako podmioty gospodarcze obowiązane są stosować ustawę o rachunkowości. Ustawa ta nie przewiduje możliwości uproszczeń rachunkowości, w tym sprawozdawczości, dla jednostek sektora publicznego (możliwości wyboru statusu jednostki mikro i jednostki małej) [Ustawa z 24 września 1994, art. 3 ust. 1e]. Wynik finansowy prezentowany jest $\mathrm{w}$ sprawozdawczości w wartościach globalnych lub z podziałem na jego komponenty. Artykuł prezentuje informacyjne aspekty wyniku finansowego szpitala w procesach decyzyjnych. Celem artykułu jest podkreślenie istotnej roli wyniku finansowego w ocenie dokonań podmiotów leczniczych - szpitali oraz podejmowaniu decyzji zarządczych przez kierownictwo zakładów i otoczenie systemowe, głównie organy tworzące.

$\mathrm{Na}$ podstawie analizy literatury przedmiotu, aktów prawnych oraz obserwacji funkcjonowania szpitali jako samodzielnych publicznych zakładów opieki zdrowotnej (spzoz) można sformułować tezę, że wynik finansowy szpitala cechuje się istotnym potencjałem informacyjnym zarówno dla kadry zarządzającej szpitalem, jak i otoczenia zakładu. Jako narzędzia badawcze wykorzystano analizę literatury, aktów prawnych oraz sprawozdań finansowych szpitali.

\section{Struktura wyniku finansowego w szpitalu}

Po nowelizacji prawa bilansowego w Polsce w wyniku finansowym szpitala wyróżnić można następujące grupy operacji wynikowych:

- koszty i przychody działalności operacyjnej,

- koszty i przychody wiążące się pośrednio z działalnością operacyjną, czyli pozostałe koszty i przychody operacyjne,

- koszty i przychody finansowe.

Koszty działalności operacyjnej dotyczą podstawowej, zasadniczej działalności medycznej i niemedycznej szpitala określonej w statucie podmiotu. W skład kosztów działalności podstawowej wchodzą koszty realizacji usług zdrowotnych oraz innych produktów (usług) świadczonych przez podmiot, koszty zarządzania podmiotem oraz inne koszty niezbędne do prowadzenia ustalonego obszaru działalności.

Do grupy pozostałych kosztów operacyjnych zalicza się takie koszty, jak:

- koszty związane z działalnością socjalną,

- wartość netto zbytych środków trwałych, środków trwałych w budowie, wartości niematerialnych i prawnych,

- odpisane należności przedawnione, umorzone, nieściągalne, z wyjątkiem należności o charakterze publicznoprawnym nieobciążających kosztów, 
- utworzenie rezerw, z wyjątkiem rezerw związanych z operacjami finansowymi,

- odpisy aktualizujące wartość aktywów i ich korekty, z wyjątkiem odpisów obciążających koszty finansowe,

- odszkodowania i kary,

- przekazanie, w tym w drodze darowizny, aktywów, w tym środków pieniężnych na różne cele,

- skutki zdarzeń losowych.

W podmiotach leczniczych - szpitalach wszystkie środki finansowe stanowiące dofinansowanie wymienionych w art. 41 ustawy o rachunkowości składników majątkowych rozliczane są za pośrednictwem konta rozliczeń międzyokresowych przychodów, równolegle do amortyzacji, na wynik finansowy, stanowiąc pozycję pozostałych przychodów operacyjnych. W poprzednich okresach dotacje i inne formy dofinansowania środków trwałych powiększały wartość funduszy szpitala [Ustawa z 14 czerwca 2012, art. 8].

Do pozostałych przychodów i kosztów operacyjnych oprócz pozycji wymienianych przez ustawę o rachunkowości zaliczane będą skutki restrukturyzacji i zdarzeń losowych oraz innych trudnych do przewidzenia, poza działalnością operacyjną jednostki i niezwiązane z ogólnym ryzykiem jej prowadzenia. Pozostałe przychody i koszty operacyjne nie są powtarzalne.

Koszty i przychody finansowe dotyczą operacji o charakterze finansowym związanych w podmiotach leczniczych z papierami wartościowymi, kredytami, pożyczkami, lokatami bankowymi i mogą występować pod postacią:

- odsetek i prowizji od zaciągniętych kredytów i pożyczek, z wyjątkiem odsetek i prowizji powiększających wartość środków trwałych, środków trwałych w budowie, wartości niematerialnych i prawnych,

- odsetek od zobowiązań i należności z tytułu zwłoki w zapłacie,

- dyskonta weksli,

- odpisów aktualizujących aktywa finansowe,

- różnic kursowych od należności i zobowiązań, z wyjątkiem różnic kursowych korygujących wartość nabytych środków trwałych, środków trwałych w budowie, wartości niematerialnych i prawnych,

- odpisów aktualizujących kwoty podwyższające należności (odsetki zwłoki w zapłacie należności),

- części odsetkowej raty leasingu finansowego,

- wartości w cenie nabycia rozchodu aktywów finansowych.

Wynik finansowy szpitala może być ustalony według wariantu porównawczego lub kalkulacyjnego. Moim zdaniem, bardziej czytelny i o większym potencjale informacyjnym jest wariant kalkulacyjny. Argumentami za taką opinią są następujące oceny:

a) zmiana stanu produktów ma ograniczony charakter, gdyż zawiera przede wszystkim zmianę stanu rozliczeń międzyokresowych, 
b) koszty prezentowane według ich rodzaju mają ograniczone walory informacyjne, nie wskazują ich związku z obszarami działalności (świadczeniami zdrowotnymi, zarządzaniem jednostką),

c) zmiana struktury kosztów według rodzaju może nie być czytelna, bez dodatkowych wyjaśnień (przykładowo, zmiana formy zatrudnienia lekarzy z umów o pracę na inne formy skutkować będzie zmniejszeniem kosztów wynagrodzeń i zwiększeniem kosztów usług) ${ }^{1}$.

Pierwsza część wyniku finansowego (wynik ze sprzedaży) odzwierciedla najbardziej istotny obszar działalności szpitala. Ma charakter powtarzalny i obrazuje trwałe relacje pomiędzy pozyskanymi przychodami a ponoszonymi kosztami². Podmioty lecznicze mogą realizować przychody z działalności usługowej, handlowej, a nawet wytwórczej, w zależności od zakresu działalności określonej w statucie podmiotu, nadanym przez podmiot tworzący ${ }^{3}$.

Koszty wynikające ze specyfiki działalności dotyczą leczenia pacjentów (koszty materiałów, usług, wynagrodzeń personelu z uwzględnieniem świadczeń na rzecz pracowników, amortyzacji) oraz zarządzania zakładem.

Planowane zmiany systemu finansowania świadczeń zdrowotnych na formę ryczałtową nie powinny zakłócać wysiłków kadry zarządzającej w kierunku szczegółowego rozpoznania struktury wyniku finansowego, przede wszystkim kosztów świadczeń. Kierownictwo szpitali, działając w granicach prawnych uwarunkowanych systemowo, podejmując decyzje zarządcze, powinno mieć informacje o ponoszonych kosztach ze względu na ocenę:

- zasadności ponoszonych kosztów,

- zgodności poniesionych kosztów ze standardami medycznymi leczenia,

- konieczności redukcji kosztów nieuzasadnionych,

- kosztów gotowości do realizacji świadczeń.

Szpital sam decyduje o podziale zysku. Jeśli poniesie stratę, powinien pokryć ją z funduszu zakładu, zgodnie z przepisami ustawy o działalności leczniczej. Ustawa

${ }^{1}$ Znajduje to potwierdzenie w wynikach badania opinii podmiotów leczniczych. Jako informacje najbardziej przydatne w zarządzaniu wskazano informacje o kosztach poszczególnych oddziałów $18,29 \%$, natomiast koszty według rodzaju wskazało $10,98 \%$ (por. [Jakimowicz 2010, s. 59]). G.K. Świderska stwierdza: „Dysponując informacjami o kosztach według rodzajów, menedżerowie nie są w stanie zarządzać kosztami, gdyż nie znają przyczyn ich powstawania. Nie mogą także ich kontrolować" (por. [Świderska 2015, s. 60]).

${ }^{2}$ Duże znaczenie wyniku na sprzedaży w rachunku wyników szpitali podkreślają także R. Orliński i M. Niestrata-Ortiz, stwierdzając: „Dążąc więc do poprawy sytuacji finansowej, zarządzający szpitalami zaczynają się bardziej interesować wynikiem na działalności podstawowej, ponieważ jest to wynik, który w pierwszej kolejności rzutuje na wynik końcowy działalności" (por. [Orliński, Niestrata-Ortiz 2016, s. 178]).

${ }^{3}$ Zgodnie z art. 55 ustawy o działalności leczniczej szpital może uzyskiwać środki finansowe m.in. z odpłatnej działalności leczniczej, innej wydzielonej działalności, jeżeli statut przewiduje prowadzenie takiej działalności, odsetek od lokat, darowizn, zapisów, spadków oraz ofiarności publicznej, także pochodzenia zagranicznego. 
ta zawiera szczegółowy zapis o skutkach ujemnego wyniku finansowego dla spzoz oraz obowiązkach jednostek samorządu terytorialnego jako podmiotu tworzącego ${ }^{4}$.

Wynik finansowy szpitala ma dużą wartość informacyjną i wykazuje ścisły związek z wartością zobowiązań podmiotów. Zbyt małe przychody (należności), nie pokrywając kosztów (zobowiązań), bezpośrednio wpływają na wzrost zadłużenia w sektorze. Jak pokazują dane statystyczne Ministerstwa Zdrowia, zadłużenie w sektorze opieki zdrowotnej wynosiło w trzech ostatnich latach (w tys. zł):

- 31 XII 2014 r. -1813469 ,

- 31 XII 2015 r. -1759384 ,

- 30 IX 2016 r. - 2017504.

Utrzymujące się na podobnym poziomie zobowiązania wymagalne świadczą o luce finansowej w zbilansowaniu sektora (nie wspominając o niesfinansowanych nadwykonaniach).

Z analiz największych 400 szpitali w 2014 r. ponad połowa, czyli 216 placówek, które znalazły się na liście, wykazało dodatni wynik finansowy, natomiast 149 szpitali poniosło straty [Jakubiak 2015, s. 33].

\section{Wynik finansowy szpitala w procesach decyzyjnych}

Podmioty lecznicze - szpitale, ustalając wynik finansowy w systemie rachunkowości, stosują zasady prawidłowej rachunkowości, zgodnie z prawem bilansowym. Wynik finansowy jest prezentowany $\mathrm{w}$ sprawozdaniu finansowym $\mathrm{w}$ rachunku zysków i strat jako efekt działalności na potrzeby sprawozdawczości zewnętrznej. W literaturze przedmiotu podkreśla się, że wynik finansowy nie jest idealnym mier-

${ }^{4}$ Art. 59. 1. Samodzielny publiczny zakład opieki zdrowotnej pokrywa we własnym zakresie stratę netto w sposób określony w art. 57 ust. 2 pkt 1.

2. Podmiot tworzący jest obowiązany w terminie:

1) 9 miesięcy od upływu terminu do zatwierdzenia sprawozdania finansowego samodzielnego publicznego zakładu opieki zdrowotnej pokryć stratę netto za rok obrotowy tego zakładu w kwocie, jaka nie może być pokryta zgodnie z ust. 1, jednak nie wyższej niż suma straty netto i kosztów amortyzacji, albo

2) 12 miesięcy od upływu terminu określonego w pkt 1 wydać rozporządzenie, zarządzenie albo podjąć uchwałę o likwidacji samodzielnego publicznego zakładu opieki zdrowotnej -jeżeli strata netto za rok obrotowy nie może być pokryta w sposób określony w ust. 1 oraz po dodaniu kosztów amortyzacji ma wartość ujemną.

3. Strata netto i koszty amortyzacji, o których mowa w ust. 2, dotyczą roku obrotowego objętego sprawozdaniem finansowym.

4. Jeżeli w sprawozdaniu finansowym wystąpiła strata netto, kierownik samodzielnego publicznego zakładu opieki zdrowotnej, w terminie 3 miesięcy od upływu terminu do zatwierdzenia sprawozdania finansowego, sporządza program naprawczy, z uwzględnieniem raportu, o którym mowa w art. 53a ust. 1, na okres nie dłuższy niż 3 lata, i przedstawia go podmiotowi tworzącemu w celu zatwierdzenia. Por. [Ustawa z 15 kwietnia 2011, art. 59]. 
nikiem osiągnięć podmiotu gospodarczego, wskazując na jego niedostatki w stosunku do innych danych sprawozdawczych na potrzeby zarządzania. Podobne zdanie można wyczytać w publikacjach na temat rachunkowości podmiotów leczniczych. Wybrane opinie na ten temat prezentuje tabela 1 .

Tabela 1. Wynik finansowy jako miernik efektywności podmiotu leczniczego

\begin{tabular}{|c|c|}
\hline Pozycja literatury & Opinie o znaczeniu wyniku finansowego \\
\hline [Jakimowicz 2010, s. 70] & $\begin{array}{l}\text { Obecnie podstawowym źródłem danych do oceny dokonań szpitala jest } \\
\text { sprawozdawczość finansowa z wynikiem finansowym jako najbardziej } \\
\text { zagregowanym miernikiem efektywności działalności. }\end{array}$ \\
\hline [Mućko 2008, s. 639, 640] & $\begin{array}{l}\text { Wynik finansowy stanowi, obok podstawowego celu ZOZ, jakim jest } \\
\text { wykonywanie świadczeń medycznych, dodatkowy cel funkcjonowania } \\
\text { tych jednostek. } \\
\text {...Aktualny kształt polskiego systemu finansowania świadczeń } \\
\text { medycznych ogranicza znaczenie wyniku finansowego jako podstawy } \\
\text { oceny kierownictwa z uwagi na znaczącą przewagę jednego płatnika } \\
\text { (NFZ) w źródłach przychodów ZOZ. Mimo to ich wynik finansowy } \\
\text { może stanowić podstawę oceny porównawczej (benchmarkingu) } \\
\text { jednostek funkcjonujących w zbliżonych warunkach. }\end{array}$ \\
\hline [Zalewska 2015, s. 78,79] & $\begin{array}{l}\text { W większości podmiotów prowadzących działalność gospodarczą } \\
\text { podstawową miarą efektywności działania jest wynik finansowy, który } \\
\text { w działalności medycznej jest niewystarczający. }\end{array}$ \\
\hline [Chluska 2014, s. 227] & $\begin{array}{l}\text { Podmioty lecznicze - spzoz wygospodarowują wynik finansowy - } \\
\text { zysk lub stratę, który stanowi element funduszu własnego podmiotu. } \\
\text { Wprawdzie spzoz nie są jednostkami komercyjnymi nastawionymi na } \\
\text { zysk, jednak ważne jest, żeby przychody nie były niższe niż koszty, } \\
\text { gdyż w długim okresie zagrażałoby to wypłacalności podmiotów } \\
\text { i kontynuowaniu przez podmiot działalności. }\end{array}$ \\
\hline
\end{tabular}

Źródło: opracowanie własne na podstawie literatury przedmiotu.

Jak pokazują opinie, wynik finansowy jest jednym z czynników oceny podmiotu leczniczego, choć należy pamiętać, że podstawowym celem działalności szpitali (czy szerzej - podmiotu leczniczego) nie jest osiąganie zysku, lecz realizacja wysokiej jakości świadczeń zdrowotnych. Równocześnie podkreśla się, że dodatni wynik finansowy jest warunkiem kontynuacji działalności podmiotu. Analizując rolę wyniku finansowego $\mathrm{w}$ procesach podejmowania decyzji w szpitalu, należy zdefiniować kryteria podziału opinii i wniosków. Różne role można przypisać temu miernikowi $\mathrm{w}$ analizach wewnątrz podmiotu oraz w jego otoczeniu. Proponowane kryteria i cechy wyniku finansowego w procesach podejmowania decyzji zawiera tabela 2.

Przywiązywanie znaczącej wagi do wartości informacyjnej wyniku finansowego podmiotu leczniczego - szpitala można również dostrzec w przepisach prawa. Projekty aktów prawnych dotyczących sieci szpitali z lat 2007, 2010 przewidywały ocenę 
Tabela 2. Wady i zalety „,wyniku finansowego” w procesach decyzyjnych

\begin{tabular}{|c|c|c|}
\hline $\begin{array}{c}\text { Kryterium } \\
\text { wyodrębnienia }\end{array}$ & Zalety parametru „wynik finansowy” & $\begin{array}{c}\text { Wady parametru } \\
\text { „wynik finansowy” }\end{array}$ \\
\hline \multirow[t]{2}{*}{$\begin{array}{l}\text { „Wynik finansowy” jako } \\
\text { informacja w procesach } \\
\text { decyzyjnych kadry } \\
\text { zarządzającej wewnątrz } \\
\text { szpitala }\end{array}$} & $\begin{array}{l}\text { - umożliwia planowanie i kontrolę } \\
\text { działalności, } \\
\text { - pozwala kadrze zarządzającej } \\
\text { podejmować decyzje strategiczne } \\
\end{array}$ & $\begin{array}{l}\text { - może zakłócać } \\
\text { realizację głównego celu } \\
\text { działalności szpitala, } \\
\text { - wykazuje mały potencjał } \\
\text { prognostyczny }\end{array}$ \\
\hline & \multirow{2}{*}{$\begin{array}{l}\text { - sposób wyliczenia wyniku finansowego } \\
\text { ustalony zasadami prawa bilansowego, } \\
\text { - jest efektem stosowania jednolitych } \\
\text { zasad nadrzędnych, } \\
\text { - zachowuje cechy dokładności, ciągłości, } \\
\text { sprawdzalności, wiarygodności } \\
\text { i rzetelności, } \\
\text { - zawsze jest dostępna informacja o jego } \\
\text { wartości, } \\
\text { - może być uniwersalną miarą do } \\
\text { porównań i analiz w systemie opieki } \\
\text { zdrowotnej, } \\
\text { - jest uwiarygodniany w procesach } \\
\text { badania sprawozdań finansowych, } \\
\text { - jest uznanym miernikiem w procesach } \\
\text { oceny podmiotów }\end{array}$} & \multirow{2}{*}{$\begin{array}{l}\text { - odwzorowuje zdarzenia } \\
\text { przeszłe, } \\
\text { - jest częściowo } \\
\text { kontrolowany przez } \\
\text { decydentów, } \\
\text { - jako wartość globalna nie } \\
\text { informuje o przyczynach } \\
\text { powstania zysku } \\
\text { lub straty, wymaga } \\
\text { dezagregacji }\end{array}$} \\
\hline \multirow[t]{2}{*}{$\begin{array}{l}\text { „Wynik finansowy” jako } \\
\text { informacja w procesach } \\
\text { decyzyjnych otoczenia } \\
\text { systemowego }\end{array}$} & & \\
\hline & $\begin{array}{l}\text { - uzasadnia decyzje systemowe } \\
\text { o procesach restrukturyzacji, } \\
\text { - może być stosowany jako element oceny } \\
\text { kadry zarządzającej. }\end{array}$ & $\begin{array}{l}\text { - może być sterowany } \\
\text { poprzez dobór zasad } \\
\text { polityki rachunkowości, } \\
\text { - porównywalność może } \\
\text { być zakłócona zmianą } \\
\text { przepisów prawa lub } \\
\text { decyzją jednostki } \\
\text { w zakresie polityki } \\
\text { rachunkowości. }\end{array}$ \\
\hline
\end{tabular}

Źródło: opracowanie własne.

sytuacji ekonomiczno-finansowej efektywności działania szpitali przy zastosowaniu analizy wskaźnikowej, opartej na wykorzystaniu wskaźników, między innymi wskaźnika zyskowności ${ }^{5}$. Nie ulega wątpliwości, że wynik finansowy jest postrzegany jako ważny miernik kondycji finansowej szpitala.

${ }^{5} \mathrm{~W}$ wyniku oceny szpital mógł uzyskać maksymalnie 100 punktów. Na podstawie oceny szpital zaliczał się do określonej kategorii stabilności ekonomiczno-finansowej. Przykładowo, kategorię „A” uzyskiwał szpital, jeżeli w wyniku oceny uzyskał co najmniej 81 punktów i dodatni wynik z działalności operacyjnej jednostki (por. [Projekt ustawy z 2007; Projekt ustawy z 2010]). 


\section{Zakończenie}

Szpitale jako publiczne zakłady opieki zdrowotnej, formułując misję swojej działalności, ukierunkowują ją na ratowanie życia, skuteczne leczenie pacjentów, zapewnienie pacjentom przyjemnych i bezpiecznych warunków leczenia, świadczenie usług zdrowotnych na najwyższym poziomie. Realizacja tak postawionych planów i oczekiwań nie jest możliwa bez odpowiedniej bazy zasobów, w tym środków finansowych na działalność. Wymusza to konieczność wypracowywania przez szpitale dodatniego wyniku finansowego. Formuła funkcjonowania szpitali jako jednostek publicznych, z perspektywą sieci szpitali, nie może bagatelizować wyniku finansowego, zwłaszcza w kontekście długookresowego rozwoju i realizacji zadań strategicznych. Wskazane w artykule argumenty precyzujące wady i zalety parametru oceny, jakim jest wynik finansowy szpitala oraz jego wartości informacyjne, potwierdzają postawioną na wstępie artykułu tezę.

\section{Literatura}

Chluska J., 2014, Rachunkowość podmiotów leczniczych, Wolters Kluwer SA, Warszawa.

Jakimowicz H., 2010, Szpital jako podmiot generowania informacji na potrzeby oceny dokonań w świetle badań, [w:] Koncepcja sprawozdawczości szpitali na potrzeby zintegrowanego systemu oceny dokonań, red. M. Hass-Symotiuk, Wydawnictwo Naukowe Uniwersytetu Szczecińskiego, Szczecin.

Jakubiak K., 2015, Lista największych szpitali w Polsce, Puls Medycyny, nr 19(312).

Mućko P., 2008, Wynik finansowy ZOZ, [w:] Rachunkowość i sprawozdawczość finansowa zaktadów opieki zdrowotnej, red. M. Hass-Symotiuk, ODDK, Gdańsk.

Orliński R., Niestrata-Ortiz M., 2016, Wynik na podstawowej działalności operacyjnej szpitala, Studia Ekonomiczne Zeszyty Naukowe Uniwersytetu Ekonomicznego w Katowicach, nr 285, Wydawnictwo UE, Katowice.

Projekt ustawy o sieci szpitali z 2007 r., http://www2.mz.gov.pl/wwwfiles/ma_struktura/docs/pust_ siecszpital_16072007.pdf (3.03.2017).

Projekt ustawy o sieci szpitali z 2010 r., http://orka.sejm.gov.pl/Druki6ka.nsf/wgdruku/3492 (3.03.2017).

Świderska G.K. (red.), 2014, Koszty w opiece zdrowotnej, Oficyna Wydawnicza Szkoły Głównej Handlowej, Warszawa.

Świderska G.K., 2015, System rachunkowości finansowej w podmiocie leczniczym i jego ograniczenia z punktu widzenia procesu zarządzania, [w:] Rachunkowość zarządcza w podmiotach leczniczych, red. G.K. Świderska, M. Pielaszek, Wolters Kluwer SA, Warszawa.

Ustawa z dnia 14 czerwca 2012 r. o zmianie ustawy o działalności leczniczej oraz niektórych innych ustaw, DzU. z 2012 r., poz. 742.

Ustawa z dnia 15 kwietnia 2011 r. o działalności leczniczej, Dz.U. z 2016 r., poz. 1638 ze zm.

Ustawa z dnia 24 września 1994 r. o rachunkowości, Dz.U. z 2016 r., poz. 1047.

Ustawa z dnia 27 sierpnia 2009 r. o finansach publicznych, Dz.U. z 2009 r., nr 157, poz. 1240 ze. zm.

Zalewska B., 2015, Rachunek kosztów szpitala na tle uwarunkowań ekonomiczno-prawnych systemu opieki zdrowotnej, Wydawnictwo Uczelniane Politechniki Koszalińskiej, Koszalin. 